\title{
Pelatihan Pencegahan Dan Deteksi Kelompok Risiko HIV/AIDS Ibu Hamil Pada Kader Kesehatan di Desa Slarang
}

\author{
Sohimah $^{1}$, Evy Apriani ${ }^{2}$, Yogi andhi Lestari ${ }^{3}$ \\ ${ }^{1}$ Prodi S1 Kebidanan STIKES Al -Irsyad Al-Islamiyyah Cilacap, ${ }^{2}$ Prodi S1 Keperawatan STIKES Al -Irsyad Al- \\ Islamiyyah Cilacap, ${ }^{3}$ Prodi D3 Kebidanan STIKES Al -Irsyad Al-Islamiyyah Cilacap \\ Email korespondensi : busohimah@gmail.com
}

\begin{abstract}
Abstrak
Provinsi Jawa Tengah. Jawa Tengah menempati urutan ke-5 untuk kasus penderita HIV dengan angka 13.547 penderita. Di Wilayah kerja Puskesmas Kesugihan 2 telah diberlakukan bahwa kepada seluruh ibu hamil untuk dilakukan pemeriksaan VCT sebagai langkah antisipati terhadap HIV/AIDS. Berdasarkan uraian diatas menjadi penting untuk dilakukan pelatihan tentang Pelatihan Pencegahan dan Deteksi Faktor Risiko HIV/AIDS Ibu hamil Pada Kader Kesehatan di Desa Slarang Wilayah kerja Puskesmas Kesugihan II.Pendekatan yang dilakukan untuk mengatasi masalah keterbatasan tersebut maka perlu dilakukan upaya untuk meningkatkan pengetahuan dan ketrampilan upaya pencegahan dan penularan HIV/AIDS dan deteksi kelompok risiko HIV/AIDS. Tujuan dari kegiatan pengabdian masyarakat ini adalah memberikan pengetahuan dan pengalaman tentang Pencegahan Dan Deteksi Kelompok Risiko HIV/AIDS sehingga dapat meningkatkan pengetahuan dan pengalaman dalam melakukan Pencegahan Dan Deteksi Kelompok Risiko HIV/AIDS. Kegiatan ini dilakukan di desa Slarang Kabupaten Cilacap. Sasaran dari kegiatan ini adalah Ibu-ibu kader Kesehatan. Kegiatan ini dilakukan dengan metode pemberian materi dan latihan melakukan Deteksi Kelompok Risiko HIV/AIDS. Hasil dari kegiatan ini adalah adanya peningkatan Pengetahuan kader kesehatan tentang pencegahan dan deteksi kelompok risiko HIV/AIDS dari nilai rata-rata Hasil pre test $15.8 \%$ sudah dalam ketegori baik menjadi 52.7\% pengetahuan kader dalam kategori baik.
\end{abstract}

Kata kunci : Kader Kesehatan.,HIV

\begin{abstract}
Province of Central Java. Central Java ranks 5th for HIV with 13,547 cases. At Puskesmas Kesugihan 2, it has been implemented that all pregnant women need to be tested for VCT as a precaution against HIV / AIDS. Based on the description above, it is important to conduct training on the HIV / AIDS Risk and Factor Detection and Prevention Training for Pregnant Women for Health Cadres in Slarang Village The working area of the Kesugihan II Health Center. The approach taken to overcome these limitations requires efforts to increase their knowledge and skills due to prevention of HIV / AIDS transmission and detection. The purpose of this community service activity is to provide knowledge and experience about the Prevention and Detection of HIV / AIDS increase knowledge and experience in carrying out HIV / AIDS Risk Group Prevention and Detection. This activity was carried out in Slarang, Cilacap Regency. The target of this activity is mothers as a health cadres. This activity is carried out using the method of providing materials and training to conduct HIV / AIDS Risk Group Detection. The result of this activity was an increase in the knowledge of health cadres about the prevention and detection of HIV / AIDS risk groups from an average value of $15.8 \%$ pre-test results were in the good category to $52.7 \%$ knowledge of cadres in the good category.
\end{abstract}

Key words: Health Cadres, HIV

Jurnal Pengabdian Masyarakat Al-Irsyad Vol. II, No. 2. Oktober 2020 


\section{PENDAHULUAN}

HIV (Human Immunodeficiency Virus) merupakan salah satu penyakit menular seksual dan merupakan virus golongan Rubonucleat Acid (RNA) yang spesifik menyerang sistem kekebalan tubuh/imunitas manusia dan menyebabkan AIDS. HIV positif adalah orang yang telah terinfeksi virus HIV dan tubuh telah membentuk zat antibodi terhadap virus. Mereka berpotensi sebagai sumber penularan bagi orang lain. AIDS adalah kumpulan gejala klinis akibat penurunan sistem imun yang timbul akibat infeksi HIV (Sarwono, 2011).

HIV/AIDS merupakan masalah kesehatan di dunia sejak tahun 1981, penyakit ini berkembang secara pandemik. Obat dan Vaksin untuk mengatasi masalah tersebut belum ditemukan, yang dapat mengakibatkan kerugian tidak hanya di bidang kesehatan tetapi juga di bidang sosial, ekonomi, politik, budaya dan demografi. Penderita HIV biasanya sulit untuk dibedakan dengan orang sehat masa inkubasi virus HIV adalah selama 10 tahun (Kementerian Kesehatan RI, 2019).

Perempuan memiliki kemungkinan yang lebih besar untuk terinveksi HIV. Kemungkinana penularan HIV dari laki-laki kepada perempuan 2-4 kali lebih besar dari pada penularan HIV dari keprempuan kepada laki-laki. Hal ini disebabkan karena perempuan memiliki selaput mukosa yang lebih luar sehingga mudah mengalami luka/iritasi. Selain itu perempuan adalah pihak yang menampung air mani, sedangkan kandungan HIV yang terdapat dalam air mani lebih banyak jumlahnya dari pada HIV dalam cairan vagina. Cara penularan HIV terbesar di Indonesia adalah melalui hubungan seksual yang tidak aman dan bergantiganti pasangan. Pada penelitian sohimah sebelumnya bahwa $19 \%$ sikap remaja mendukung terhadap perilaku penyimpangan seksual, sehingga potensi penularan HIV menjadi lebih besar (Sohimah \& Apriani, 2019). Kondisi ini meningkatkan resiko penularan HIV sehingga dapat meningkatkan kejadian wanita hamil yang disertai HIV positif yang pada akhirnya akan sangat berisiko untuk melahirkan bayi dengan HIV positif.

HIV/AIDS kini tidak saja merambah di kota-kota besar di Indonesia. Tetapi kini penyebarannya sudah mencapai di seluruh provinsi di Indonesia. Salah satunya di Provinsi Jawa Tengah. Jawa Tengah menempati urutan ke-5 untuk kasus penderita HIV dengan angka 13.547 penderita. Urutan pertama diduduki oleh provinsi DKI Jakarta dengan angka 40.500 kasus penderita HIV. (DITJEN P2P Kemenkes RI, 2016). Di Indonesia upaya pencegahan dan pemeriksaan kasus HIV AIDS perlu ditingkatkan lagi untuk mempercepat penurunan angka kematian akibat HIV/AIDS. Adanya Perda Kabupaten Cilacap Nomor 2 Tahun 2015 tentang 
Penanggulangan HIV dan AIDS di Kabupaten Cilacap merupakan langkah nyata pemerintah dalam upaya mencegah peningkatan kasus HIV/AIDS, termasuk program pencegahan HIV/AIDS dari ibu ke janin.

Berdasarkan informasi dari kepala VCT RSUD Cilacap bahwa berdasarkan data yang ada dalam akumulasi 10 tahun terakhir tercatat 983 kasus HIV/AIDS di Kabupaten Cilacap dan menjadikan Cilacap dalam urutan ke 3 diPropinsi Jawa Tengah. Berdasarkan hasil penelitian yang dilakukan oleh Sohimah dan tim pada tahun 2018, dari jumlah tersebut $75,6 \%$ pengidap HIV/AIDS berasal dari kelompok usia reproduksi sehat yaitu usia 20-35 tahun. Selain itu didapatkan hasil juga bahwa di RSUD Cilacap wanita hamil dengan HIV (+) selama periode tahun 2013 - 2017 adalah sebanyak 45 orang. Selain Berdasarkan Survey pendahuluan yang dilakukan pada tanggal 9 Maret 2020 diperoleh data bahwa selama tahun 2019 terdapat 18 kasus ibu hamil dengan HIV (+) yang kemudian melahirkan dirumah sakit dengan 17 sectio cesaria dan 1 persalinan pervaginam. Di Wilayah kerja Puskesmas Kesugihan 2 telah diberlakukan bahwa kepda seluruh ibu hamil untuk dilakukan pemeriksaan VCT sebagai langkah antisipati terhadap HIV/AIDS. Namun demikian belum semua ibu hamil dan kader memahami tentang HIV/AIDS dan dampak terhadap kehamilan serta bagaimana cara pencegahannya (Rumah Sakit Umum Daerah Cilacap, 2017),(Dinas Kesehatan Kabupaten Cilacap, 2017).

Kader Kesehatan adalah setiap orang yang dipilih oleh masyarakat dan dilatih untuk menggerakkan masyarakat berpartisipasi dalam pemberdayaan masyarakat bidang Kesehatan, yang salah satu strateginya adalah peningkatan pengetahuan dan kemampuan masyarakat dalam mengenali dan mengatasi permasalahan kesehatan yang dihadapi. Penting sekali untuk kader kesehatan mengetahui cara mencegah penularan dan bagaimana kelompok risiko HIV/AIDS. Berdasarkan uraian diatas menjadi penting untuk dilakukan pelatihan tentang Pelatihan Pencegahan dan Deteksi Faktor Risiko HIV/AIDS Ibu hamil Pada Kader Kesehatan di Desa Slarang Wilayah kerja Puskesmas Kesugihan 2.

Berdasarkan pemikiran tersebut diatas, maka perlu diadakan suatu langkah preventif kepada kelompok kader kesehatan yang telah terbentuk tersebut sebagai upaya untuk meningkatkan minat dan peran semua kader kesehatan sehingga dapat meningkatkan pengetahuan dan kemampuan dalam melakukan upaya pencegahan terhadap penularan HIV/AIDS dan identifikasi kelompok risiko tinggi HIV/AIDS sehingga mampu melakukan upaya-upaya pencegahan dan mengenali kelompok-kelompok risiko tinggi penularan 


\section{HIV/AIDS.}

Kegiatan ini diawali dengan pre tes tentang pencegahan penularan Hiv/Aids dan deteksi faktor risiko tinggi, sebagai langkah apersepsi dalam pemberian materi tentang kehamilan risiko tinggi. Selanjutnya dilakukan pemberian pelatihan tentang cara melakukan deteksi adanya kehamilan risiko tinggi dan menjadi konselor bagi ibu hamil dengan atau tanpa Hiv/Aids. Harapannya dengan pelatihan tersebut, kader kesehatan didesa Slarang akan selalu kontinyu melakukan upaya-upaya pencegahan terhadap HIV/AIDS dan deteksi dini terhadap kelompok-kelompok risiko HIV/AIDS sehingga pada akhirnya dapat menurunkan AKI dan $\mathrm{AKB}$.

\section{MASALAH}

Berdasarkan hasil observasi dilapangan oleh tim pengusul melalui wawancara dengan bidan desa dan salah satu kader kesehatan didesa Slarang didapatkan data bahwa di Desa Slarang masih adanya masyarakat khususnya ibu hamil yang belum memahami tentang bagaimana upaya-upaya pencegahan dan agar tidak tertular HIV/AIDS. Selain itu ibu hamil dan kader kesehatan juga belum memahami tentang kelompok risiko tinggi tertularnya HIV/AIDS. Sehingga permasalahan yang terjadi Desa Slarang Kec. Kesugihan adalah:

1) Bagaimanakah pengetahuan kader kesehatan di Desa Slarang tentang HIV/AIDS pada ibu hamil?

2) Bagaimanakah kemampuan kader kesehatan di Desa Slarang upaya pencegahan HIV/AIDS?

\section{METODE}

Pendekatan yang dilakukan untuk mengatasi masalah keterbatasan tersebut maka perlu dilakukan upaya untuk meningkatkan pengetahuan dan ketrampilan upaya pencegahan penularan HIV/AIDS dan deteksi kelompok risiko HIV/AIDS. Berdasarkan identifikasi masalah yang muncul dalam rumusan masalah, maka kami menawarkan solusi permasalahan melalui serangkaian kegiatan dengan melibatkan partisipatori aktif dari kelompok Kader Kesehatan. Pada kegiatan pengabdian ini bentuk kegiatannya terdiri dari dua kegiatan yaitu, pemberian materi melalui penyuluhan tentang pencegahan penularan HIV/AIDS dan latihan mempraktekan cara melakukan deteksi kelompok risiko HIV/AIDS. Rangkaian kegiatan 
yang telah dilakukan adalah sebagai berikut:

1) Memaksimalkan peran aktif kelompok kader kesehatan desa Slarang Melakukan Pre test tentang HIV/AIDS, pencegahan dan deteksi dini kelompok risiko HIV/AIDS pada dan kader kesehatan.

2) Pada sesi ini merupakan langkah untuk mengetahui sejauh mana pengetahuan dan pemahaman kelompok kader kesehatan tentang HIV dan pencegahannya serta deteksi kelompok risiko tinggi penularan HIV/AIDS. Hal ini akan bermanfaat dalam proses pemberian materi tentang HIV dan pencegahannya serta deteksi kelompok risiko tinggi penularan HIV/AIDS oleh kader kesehatan nantinya.

3) Pemberian materi tentang HIV dan pencegahannya serta deteksi kelompok risiko tinggi penularan HIV/AIDS. Kegiatan pada sesi ini bertujuan untuk meningkatkan pengetahuan dan pemahaman ibu-ibu kader kesehatan desa Slarang tentang HIV dan pencegahannya serta deteksi kelompok risiko tinggi penularan HIV/AIDS sebagai dasar untuk meningkatkan ketrampilan deteksi dini tentang tanda kehamilan risiko tinggi. Pada sesi ini diberikan ketrampilan bagaimana cara melakukan deteksi dini tanda kehamilan risiko tinggi. Pada akhir sesi kemudian dilakukan post test.

4) Praktek deteksi kelompok risiko terhadap penularan HIV/AIDS dan menjadi cara menyuruh beberapa peserta melakukan deteksi terhadap factor resiko dengan cara menggunalkan kartu deteksi factor resiko HIV/AIDS. Pada bagian ini dilakukan Praktek langsung kepda ibu hamil oleh kader kesehatan dan sekaligus latihan bagaimana cara memberikan pendidikan kesehatan tentang HIV dan pencegahannya serta deteksi kelompok risiko tinggi penularan HIV/AIDS serta memberikan konseling kepada ibu hamil. Selanjutnya bersama bidan desa setempat dipilih yang pada saat pemberian materi dan praktek ketrampilan aktif bertanya utuk dijadikan pengurus kelompok konselor. Out come dari kegiatan ini adalah konselor terpilih mampu memberikan konesling dan tindakan-tindakan deteksi kelompok risiko tinggi penularan HIV/AIDS

\section{HASIL DAN PEMBAHASAN}

\section{1) Hasil}

Pelaksanaan kegiatan ini dilaksanakan pada pada Hari Rabu tanggal 22 Juli 2020 dimulai jam 08.00 s.d 12.00.00 bertempat di Slarang Kecamatan Kesugihan, Kabupaten Cilacap. Peserta pelatihan sebanyak 19 orang, yang terdiri dari ibu-ibu kader Kesehatan. 
Tabel 1. Tabel Pengetahuan Kader Kesehatan Sebelum dan Sesudah di berikannya Materi pencegahan dan deteksi kelompok risiko tinggi penularan HIV/AIDS

\begin{tabular}{lcccc}
\hline \multirow{2}{*}{ Pengetahuan } & \multicolumn{2}{c}{ Sebelum } & \multicolumn{2}{c}{ Sesudah } \\
\cline { 2 - 5 } Baik & F & $\%$ & F & $\%$ \\
\cline { 2 - 5 } Cukup & 3 & 15.8 & 10 & 52.7 \\
Kurang & 4 & 21.0 & 4 & 21.0 \\
\hline Jumlah & 12 & 63.2 & 5 & 26,3 \\
\hline
\end{tabular}

Tabel 1 menunjukkan hasil bahwa terjadi peningkatan pengetahuan ibu sebelum dan sesudah kegiatan Hasil pre test $63.2 \%$ pengetahuan kader dalam kategori kurang baik. Namun 15.8\% sudah dalam ketegori baik, hal ini dimungkinkan karena beberapa kader yang dipilih sudah pernah terpapar pendidikan kesehatan tentang HIV/AIDS melalui media elektronik maupun dari tenaga kesehatan. Pada saat Pemberian Materi Kader antusias dan fokus thd materi yang disampaikan, terbukti ditengah penyampaian materi banyak kader yang bertanya dan menyampaikan pengalaman-pengalamanya selama menjadi kader Kesehatan. Post-test yang dilakukan pada hari sabtu tgl 22 Agustus 2020 dengan hasil post test $52.7 \%$ pengetahuan kader dalam kategori baik. Namun masih ada 26.3\% dalam kategori pengtahuan kurang. Hal ini dimunkinkan karena tingkat pendidikan kader yang beaneka ragam sehiangga berpengaruh terhadap tingkat keterserapan.

Berdasarkan hasil evaluasi kader Kesehatan dapat melakukan simulasi memberikan pendidikan kesehatan tentang HIV/AIDS. Kader Kesehatan juga mempraktekan cara melakukan deteksi dini faktor resiko HIV/AIDS pada ibu hamil dengan menngunakan kartu deteksi dini, deteksi faktor resiko dengan menggunakan kartu deteksi faktor resiko HIV/AIDS dengan praktek pemberian materi.

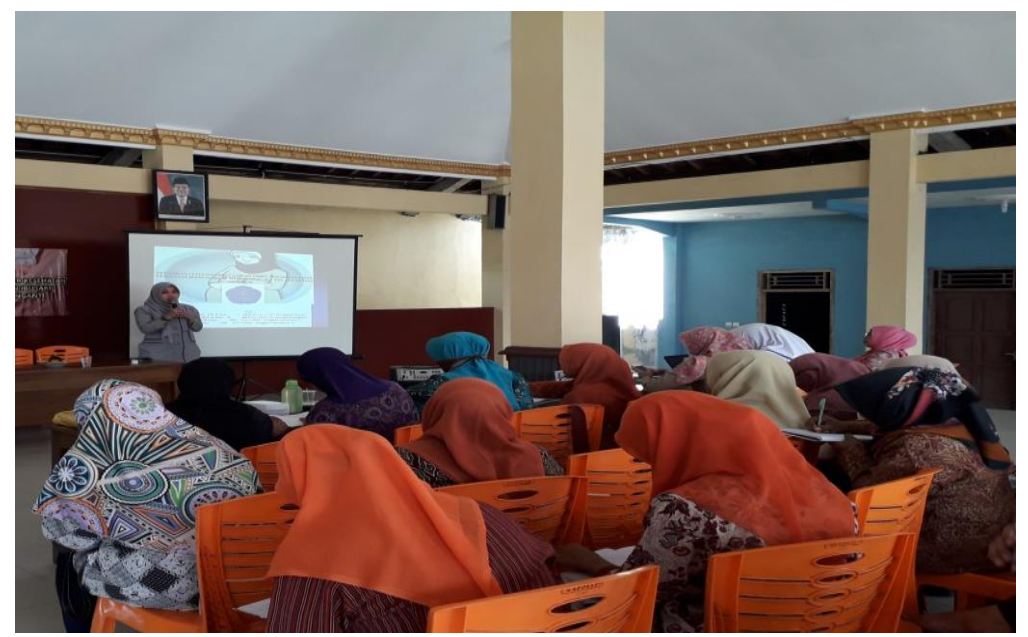

Gambar 4.1 : Pemberian Materi 


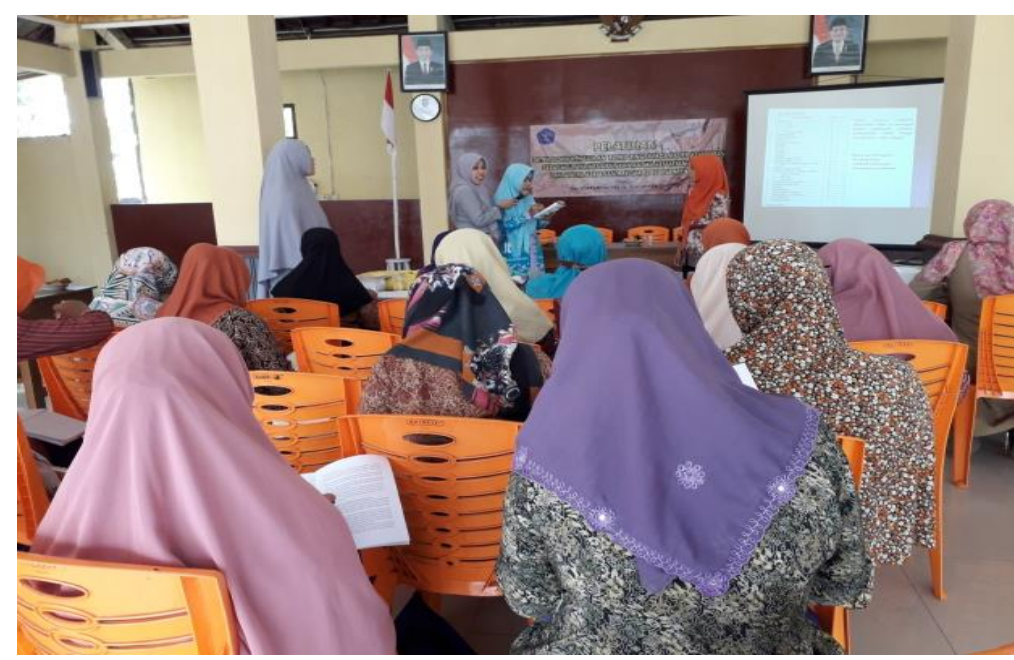

Gambar 4.2. Praktek/latihan deteksi dini oleh kader kesehatan

\section{2) Pembahasan}

Kelompok ibu hamil merupakan kelompok rentan untuk tertularnya HIV/AIDS. Hal ini terjadi karena daya tahan ibu hamil menurun seiring dengan kehamilnnaya. Peningkatan Pengetahuan dan kemampuan Ibu hamil tentang Deteksi dan pencegahan HIV/AIDS dilakukan dengan dilaksanakannya pelatihan yang dilakukan terhadap Kader Kesehatan. Hal ini dikarenakan jika kader Kesehatan memahami Deteksi dan pencegahan HIV/AIDS maka kader Kesehatan dapat memebrikan Pendidikan Kesehatan tentang Deteksi dan pencegahan HIV/AIDS pada ibu hamil kapan saja dibutuhkan tanpa mengandalkan tenaga Kesehatan. Kader kesehatan masyarakat adalah laki-laki atau wanita yang dipilih oleh masyarakat dan dilatih untuk menangani masalah-masalah kesehatan perseorangan maupun masyarakat serta untuk bekerja dalam hubungan yang amat dekat dengan tempat-tempat pemberian pelayanan Kesehatan.

Pemberian pelatihan tentang pencegahan dan deteksi penularan HIV/AIDS terbukti meningkatan pengetahuan dan kemampuan kader kesehatan berkaitan dengan Pencegahan dan Deteksi Kelompok Risiko HIV/AIDS dari nilai rata-rata Hasil pre test 15.8\% sudah dalam ketegori baik menjadi $52.7 \%$ pengetahuan kader dalam kategori baik. Hal ini dikarenakan Pemberian Pendidikan kesehatan merupakan suatu bentuk tindakan mandiri tenaga kesehatan untuk membantu klien baik individu, kelompok, maupun masyarakat dalam mengatasi masalah kesehatannya melalui kegiatan pembelajaran yang didalamnya tenaga kesehatan. Pendidikan kesehatan adalah upaya persuasi atau pembelajaran kepada masyarakat agar masyarakat mau melakukan tindakan -tindakan untuk memelihara, dan meningkatkan taraf 
kesehatannya (Notoatmodjo. S., 2012), (Supardi. Sudibyo dan Rustika, 2013).

Kegiatan diawali dengan penjelasan materi menggunakan metode Pendidikan kesehatn ceramah dan demontrasi / latihan dengan dan kemudian dilanjutkan dengan bimbingan tekhis cara melakukan Pendidikan kesehatan. Setelah selesai kegiatan peserta diharapkan dapat mempraktekan langsung dan memberikan Pendidikan Kesehatan kepada ibu hamil khususnya dan masyarakat pada umumnya serta dapat melakukan deteksi dini terhadap adanya faktor risiko tinggi terhadap penularan HIV/AIDS. Kegiatan ini membutuhkan tindak lanjut dan kerjasama dengan kader dan petugas kesehatan setempat sehingga kegiatan bisa berkelanjutan dan memberikan banyak manfaat untuk kelompok Ibu hamil yang berisiko tinggi terhadap penularan HIV/AIDS.

\section{KESIMPULAN}

Kesimpulan yang dapat diambil dari kegiatan pengabdian masyarakat Pelatihan Pencegahan Dan Deteksi Kelompok Risiko HIV/AIDS di desa Slarang ini adalah terdapat peningkatan pengetahuan kader kesehatan berkaitan dengan Pencegahan Dan Deteksi Kelompok Risiko HIV/AIDS.

\section{DAFTAR PUSTAKA}

Dinas Kesehatan Kabupaten Cilacap. (2017). Profil Kesehatan Kabupaten Cilacap Tahun 2017. Dinas Kesehatan Kabupaten Cilacap.

DITJEN P2P Kemenkes RI. (2016). Laporan Situasi Perkembangan HIV \& AIDS di Indonesia Jan-Maret 2016. Kemenkes RI.

Kementerian Kesehatan RI. (2019). Peraturan Menteri Kesehatan Nomor 8 Tahun 2019. Permenkes Nomor 8 Tahun 2019 tentang Pemberdayaan Masyarakat Bidang Kesehatan. KEPMENKES RI.

Notoatmodjo. S. (2012). Promosi Kesehatan dan Perilaku Kesehatan. Rineka Cipta.

Rumah Sakit Umum Daerah Cilacap. (2017). RSUD Cilacap, Laporan Klinik VCT 2017. Rumah Sakit Umum Daerah Cilacap.

Sarwono, P. (2011). ILMU KANDUNGAN. Bina sarwono prawirohardjo.

Sohimah, \& Apriani, E. (2019). Faktor-faktor yang mempengaruhi Kejadian HIV/AIDS di RSUD Cilacap periode Tahun 2013-2017. 
Supardi. Sudibyo dan Rustika. (2013). Buku Ajar Metodologi Riset Keperawatan. CV. Trans Info Media. 